\title{
READING TO LEARN AND EFL Students' Construction of Spoken Biographical ReCOUNTS
}

\author{
EL MÉtOdo LEER PARA APRENDER Y LA CONSTRUCCIÓN DE RELATOS BIOGRÁfiCOS ORALES \\ POR PARTE DE ESTUDIANTES DE INGLÉS COMO LENGUA EXTRANJERA
}

\author{
La méthode Lire pour Apprendre et la CONSTRUCtion de racontes \\ BIOGRAPHIQUES À L'ORAL PARMi DES ÉTUdiANTS D'ANGLAIS LANGUE ÉTRANGère
}

\author{
José David Herazo \\ Ph. D. in Language, Literacy, and \\ Culture, University of Pittsburgh, USA. \\ Full-time Professor, Universidad de \\ Córdoba, Colombia. \\ https://orcid. \\ org/0000-0001-8038-868X \\ jdherazo@correo.unicordoba.edu.co
}

\section{Tatiana Becerra}

M. A. in Applied Linguistics,

Universidad de Jaén, Spain.

Full-time Teacher, Universidad de

Córdoba, Colombia.

https: //orcid.

org/0000-0003-3156-6907

tatianabecerra@correo.unicordoba.

edu.co

\section{Paula García-Montes}

Master in Education, Universidad del

Norte, Colombia.

Full-time Teacher, Universidad de

Córdoba, Colombia.

pgarciamontes@correo.unicordoba.

edu.co

https://orcid.

org/0000-0003-4443-1091

\section{Anamaría Sagre-Barboza}

Master in Education, Universidad del

Norte, Colombia.

Full-time Teacher, Universidad de

\begin{abstract}
Reading to Learn (R2L) is a genre-based pedagogical model that has been used worldwide for promoting student literacy in L1 and L2 contexts. Despite its increasing popularity, very few studies have reported how R2L can be used to support learners' spoken communication in foreign language classrooms. This article reports the results of a qualitative study that explored how a rural-school teacher of EFL used this model to support ninth graders' understanding and production of spoken biographical recounts. Findings revealed that learners' spoken meaningmaking potential increased during the R2L lessons, both in terms of the amount of new content students conveyed throughout the stages and phases of the genre and in connection with the variety of lexico-grammatical resources learners used. Findings also revealed that the teacher's use of metalanguage, both verbally and represented in a diagram, became a key scaffold in students' independent construction of biographical recounts. The study underscores the value of this pedagogy for promoting spoken discourse in EFL classrooms.
\end{abstract}

Keywords: spoken discourse; systemic functional linguistics; Reading to Learn; biographical recounts; genre-based instruction; EFL.

\section{RESUMEN}

Leer para Aprender (LPA) es un modelo pedagógico basado en el concepto de género textual que se ha utilizado en todo el mundo para el desarrollo de la alfabetización académica de los estudiantes en contextos de lengua materna y lengua extranjera. A pesar de su creciente popularidad, muy pocos estudios se han ocupado de cómo se puede utilizar este modelo para apoyar la comunicación oral de los alumnos en el aula de idiomas extranjeros. Este artículo presenta los resultados de un estudio cualitativo que exploró cómo un profesor de inglés como lengua extranjera (ILE) de escuela rural usó el modelo pedagógico para apoyar la comprensión y la producción de relatos biográficos orales en inglés por parte de estudiantes de noveno grado. Los hallazgos del estudio muestran que el potencial de significación oral de los estudiantes aumentó durante las clases con esta estrategia, tanto en relación con la

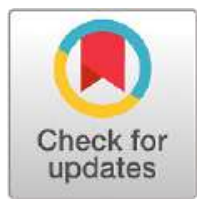


Córdoba, Colombia.

https://orcid.

org/0000-0001-8088-1685

anamariasagre@email.arizona.edu

\section{Camila Anaya-Gil}

B. A. in English Language Teaching, Universidad de Córdoba, Colombia. https://orcid.

org/0000-0001-7268-0402

camilaanayagil@gmail.com

\section{Juliana Pastrana}

B. A. in English Language Teaching, Universidad de Córdoba, Colombia. https: //orcid.

org/0000-0001-7052-1600

julianapastrana98@hotmail.com cantidad de nuevo contenido que los estudiantes pudieron expresar en las etapas y fases del género como en la variedad de recursos lexicogramaticales que usaron para tal fin. Los hallazgos también muestran que el uso de metalenguaje por parte del profesor, tanto verbalizado como representado en un diagrama, se convirtió en andamiaje central para la construcción independiente de los relatos biográficos de los estudiantes. Este estudio resalta la utilidad de este modelo para la promoción del discurso oral en las aulas de ILE.

Palabras clave: discurso hablado; lingüística sistémico.funcional; Leer para Aprender; recuentos biográficos; pedagogía de género; ILE.

\section{RÉSUMÉ}

Lire pour Apprendre (LPA) est un modèle pédagogique qui fait appel au concept de genre textuel. Ceci a été utilisé dans le monde entier pour le développement de l'alphabétisation des élèves dans des contextes de langue maternelle et de langue étrangère. Malgré sa popularité croissante, très peu d'études ont abordé la manière dont ce modèle peut être utilisé pour soutenir la communication orale des apprenants dans l'apprentissage des langues étrangères. Cet article présente les résultats d'une étude qualitative qui a exploré comment un enseignant d'anglais langue étrangère dans une école rurale a utilisé le modèle pédagogique pour soutenir la compréhension et la production de récits biographiques oraux en anglais par des élèves de neuvième année. Les résultats de l'étude montrent que le potentiel des élèves pour la signification orale a augmenté pendant les cours avec cette stratégie, à la fois en relation avec la quantité de contenu nouveau que les élèves ont pu exprimer dans les étapes et les phases du genre et dans la variété des ressources lexicogrammatiques. qu'ils ont utilisé à cette fin. Les résultats montrent également que l'utilisation du métalangage par l'enseignant, à la fois verbalisée et représentée dans un diagramme, est devenue un échafaudage central pour la construction indépendante des récits biographiques des élèves. Cette étude met en évidence l'utilité de ce modèle pour la promotion du discours oral dans les classes d'anglais langue étrangère.

Mots-clés : discours oral ; linguistique fonctionnelle systémique ; Lire pour Apprendre ; racontes biographiques; pédagogie des genres ; anglais langue étrangère. 


\section{Introduction}

Reading to Learn (R2L) is a genre-based pedagogical model that seeks to promote students' independent meaning-making in both reading and writing across the school curriculum (Rose \& Martin, 2012). Like other genre-based models (see Martin, 1999 and Martin \& Rose, 2012 for a revision), R2L follows a cycle of three stages through which teachers prepare students to understand an exemplar text from a genre, then the teacher and students construct a new text together, and finally students construct another text in the same genre independently. Extensive research has demonstrated how genre-based pedagogy aids teachers to develop learners' meaning-making potential in reading and writing at high school and college levels (Achugar, 2003; Achugar \& Carpenter, 2012; Boccia et al., 2013; Brisk \& de Rosa, 2014; Byrnes et al., 2010; Coffin, 2006; de Oliveira \& Iddings, 2014; Dreyfus et al., 2016; Gebhard et al., 2007; Humphrey \& Feez, 2016; Joyce \& Slade, 2000; Schleppegrell et al., 2014; Whittaker \& Lövstedt, 2017). R2L grounded research has also illustrated significant L1 and L2 literacy gains among low achievers (Martin \& Rose, 2008; Whittaker \& Acevedo, 2016; Millin \& Millin, 2014). Becerra et al. (2019) illustrated how R2L helped EFL students to improve their results in reading tasks, providing them with strategies to read explanation texts independently.

Although genre-based research has flourished in the past two decades, few studies have explored how this pedagogy, and R2L in particular, can facilitate the teaching and learning of students' spoken L2 discourse. Joyce and Slade (2000) argued that the use of authentic and comprehensive dialogues accompanied by the study of their identifiable generic structure could become a springboard for the teaching and learning of oral conversational genres (i.e., recounts, anecdotes, storytelling). Banks (2000) echoed Joyce and Slade's genre-based orientation (2000), illustrating how the familiarization and rehearsal of a generic structure of casual conversation helped students negotiate the existing structure and successfully engage in long casual conversations. McKay et al. (2000) also reported how the identification and implementation of five co-constructed teaching and assessing strategies facilitated improvement of students' casual conversation skills and propelled independent learning. Khatibi (2014) demonstrated through a quasi-experimental study that genre-consciousness tasks based on Benedict's model (2006) helped Iranian students perform significantly better in standardized speaking tests which included diverse spoken genres (e.g., recounts, reviews, biographies).

More specifically, Wilkins (2018) illustrated how the study of the recount genre, along with the combination of a negotiated genre model (deconstruction, joint construction, and self-construction), helped Japanese learners of English add more clauses to their utterances and complete oral tasks more successfully. Interestingly, Wilkins explained that, while students engaged in conversations more successfully, they still had limitations to initiate talks spontaneously with the teacher and other peers. Not unlike Wilkins, Herazo (2014) reported how genre-based pedagogy could be used to promote high school students' meaning-making in shopping exchanges and spoken recipe procedure genres, emphasizing the use of a metalanguage as conceptual tools that learners could use to support their attempts to create meaning in English as a foreign language (EFL). Fernandez (2017) and Fernandez and Donato (2020) have also explained how the study of the genre of service encounters, accompanied by the Schema of a Complete Orienting Basis of Action ( engage in conversation during a study abroad experience.

To our knowledge, no research has used R2L for supporting students' spoken meaning-making potential in a new language. Thisstudy adds to current R2Land genre-based research by illustrating how R2L helped students increase this potential in spoken biographical recounts in an EFL classroom. The study 
addressed two research questions: (1) What are the changes which may occur in students' meaning-making potential in spoken EFL discourse during R2L lessons, and (2) in what ways may the teachers' use of metalinguistic knowledge contribute to such changes?

\section{Theoretical Framework}

The following section describes the founding principles of R2L and provides thorough details of its stages.

\section{The Reading to Learn Approach}

\section{R2L draws from Systemic Functional Linguistics'} (SFL) view that language is a semiotic resource for making meaning in social contexts (Halliday \& Matthiessen, 2004). Language offers a variety of options from which users can choose to respond to the semantic demands of particular situations and cultural purposes. From this view, it follows that R2L conceives language learning as the expansion of the semiotic resources learners can use to make meanings in context (Christie, 2004; Halliday, 1993).

R2L is also based on SFL's premise that any language use in context comprises texts that, in turn, belong into specific genres (Christie, 2004). A text is any instance of language use in communication involving a person who means, some form of meaning, and a person to whom that meaning is addressed (Hasan, 2004). Genres are patterned ways of language use that respond to the demands of particular social contexts (Derewianka, 1990; Halliday \& Matthiessen, 2004; Martin \& Rose, 2007). These include, for example, the way language is used to explain a recipe procedure or the way a biographical recount describes the life events of a person. Genres are classified according to their primary social purposes: Narratives tell a story, usually to entertain; and instructions tell people what to do, while expository texts argue a viewpoint (Derewianka, 2003).
Not unlike other genre-based models inspired by SFL, R2L follows the principle that the patterned ways of using language in genres should be made explicit to learners (Schleppegrell, 2004). To this end, R2L favors the use of a shared metalanguage (i.e., language to talk about language) as a pedagogical resource to talk about texts and thus promote learners' awareness of how language works to create various kinds of meanings (Humphrey \& Macnaught, 2011). Examples of such metalanguage are the specialized terminology used in SFL (e.g., orientation, complication, resolution) or the one teachers and students may customize (e.g., action, reaction, interaction; Humphrey \& Feez, 2016) to scaffold students' understanding and creation of texts.

$\mathrm{R} 2 \mathrm{~L}$ is also based on the sociocultural view (Vygotsky, 1978; Gibbons, 2003) that learning occurs thanks to guidance from others in the context of meaningful tasks. Hence, R2L proposes a series of support strategies to enable students to read and write various kinds of genres independently (Rose \& Martin, 2012). These strategies are organized along three levels of support, from understanding and producing whole texts to

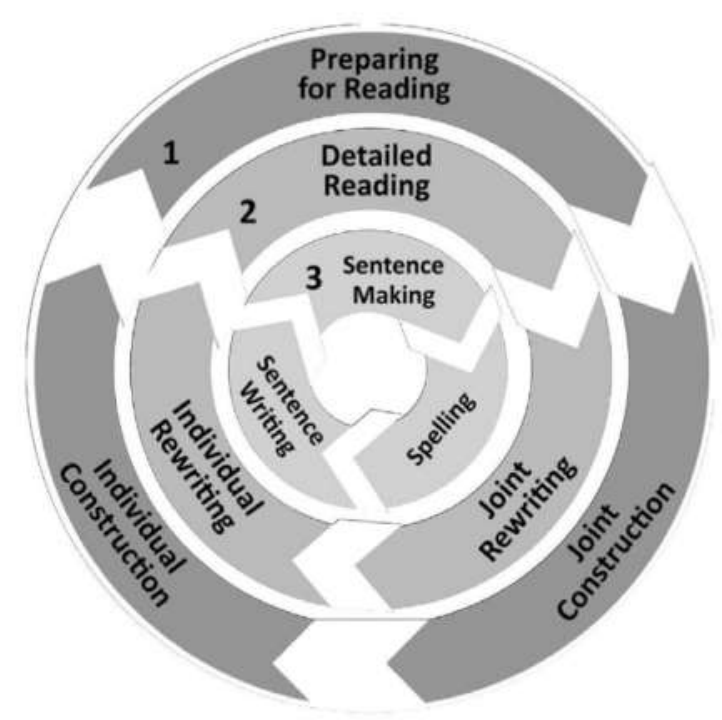

Figure 1 Reading to learn cycle 
becoming aware and using the wordings of discrete clauses (Figure 1).

The first level of support focuses on whole texts and comprises three stages: preparing for reading, joint construction, and independent construction (the outer layer of the cycle in Figure 1). Preparing for reading supports students to read along the text with a general understanding of its context of situation and culture. Students' background knowledge of the genre type is activated by briefly explaining to the students what the text is about and pointing at its schematic structure. Then, a summary of the text is provided to give more intensive support by telling students how the text unfolds step by step. The purpose of this stage is to reduce the semiotic load of trying to understand a model text of the genre learners would use in the next stage. In joint construction, the teacher and the students collaboratively deconstruct the stages and phases of the model text and jointly construct a new one organized with the same schematic structure. During independent construction, students can work individually or in groups to write a new text of the same genre independently. Based on the current level of students, the teacher can decide on providing little or no support to the groups during this stage of the cycle.

The second level of support, the intermediate layer in Figure 1, focuses on key segments of texts and comprises three other stages: detailed reading, joint rewriting, and individual rewriting. These stages help students understand how groups of words create meaning in clauses (Rose \& Martin, 2012). In detailed reading, teachers support students' understanding of the text following a carefully planned, three-part interaction cycle. First, teachers prepare students by reading sentence by sentence, summarizing the meaning of the whole clauses in language students can understand and telling the position cue of the wordings to be read. Second, students engage in the learning task, identifying, in the text, the wordings previously signaled through the teacher cues. Last, teachers affirm and elaborate on students' answers by explaining the wording's actual meaning or how they make sense in the text (Rose, 2015). This stage enables students to understand and participate by elaborating meaning, defining terms, and explaining relevant concepts from the text (Rose, 2008). In joint rewriting, students, along with the teacher, use the words they highlighted in the previous stage to brainstorm ideas on the board in order to reconstruct the text using their understanding from detailed reading. Finally, in individual rewriting, students use the notes to rewrite the same segment of text on their own.

The third level of support focuses on sentences and comprises sentence making, spelling, and sentence rewriting (the innermost cycle in Figure 1). These stages help learners to understand how letters are arranged, and how groups of words, sentences and clauses create meaning in the genre. At the level of words and sentences, students learn how to select elements of the texts and organize them into coherent and well written sentences and sequences (Rose, 2008).

The strategies used within the cycle can be used flexibly to accommodate students' needs, proficiency, and genre type (Rose \& Martin 2012). For instance, teachers can think of engaging learners in joint construction after the preparing for reading stage, depending on their English level. Similarly, the teacher may select the skill to emphasize, for example, adapting the R2L cycle for teaching spoken discourse (as is the case of this study) or focusing on reading over writing (Becerra et al., 2019; Benítez et al., 2018).

Becerra et al. (2019) report how a high school teacher adapted the R2L cycle to promote ninth graders' comprehension of explanation texts in EFL during six lessons. For instance, the teacher privileged a focus on lexicogrammar during the step-by-step summary before actual reading and detailed reading, which appeared to be material for developing students' understanding of explanations. Similarly, Benítez et al. (2018) focused on students' critical reading and thus added the 
stages of building context, purpose and structure of the text, detailed reading, re-representation of ideas from the text, reaction to it, and self-assessment. They also incorporated conscious attention to reading strategies by the teacher.

\section{Methods}

This qualitative study (Richards, 2003) aimed to explore the changes in students' meaning-making that ensued from a high-school teacher's implementation of R2L to develop spoken discourse. Consistent with the nature of qualitative research, the study focused on understanding how R2L was used in an unaltered high-school classroom and documenting the qualitative changes that occurred in EFL learners' spoken discourse as a result.

\section{Context and Participants}

Participants were an EFL teacher, $\mathrm{Mr}$ Noel (pseudonym), and his 14-16-year-old ninth graders in a small rural state school in Colombia. Mr. Noel is an experienced teacher who holds a bachelor's degree in English language teaching and a masters' degree in education. Mr. Noel was invited to participate in the study because of his reputation as a successful EFL teacher who frequently sought out professional development. At the beginning of this study, his students were beginning EFL learners who could introduce themselves or describe friends orally using basic language but usually struggled to follow L2 instructions.

\section{The Reading to Learn (R2L) Program}

The R2L professional development program consisted of four 3-hour workshops based on R2L teacher resource books (Reading to Learn, 2007) and five collaborative lesson planning sessions that helped Mr. Noel: (1) understand the concept of text, (2) identify different genres, (3) recognize R2L strategies, and (4) integrate them into his R2L lessons. Mr. Noel's R2L lessons focused on ninth graders' ability to recount life events orally through two biographical recounts (Steve Jobs and famous Colombian singer, Martín Elias) over four lessons.
Rather than implementing it rigidly, Mr. Noel and researchers modified the $\mathrm{R} 2 \mathrm{~L}$ model to suit learners' needs to develop spoken discourse, adapting the stages of the R2L as follows: Preparing for listening, Detailed listening, Joint retelling, Joint construction and Independent speaking. During Preparing for listening, Mr. Noel described to students the purpose and typical stages of a biographical recount by pointing to Steve Jobs' biography and mentioning the key stages and events that students eventually watched in a video. For Detailed listening, students watched the video again while reading its transcript. Mr. Noel followed Martin and Rose's (2008) interaction cycle, pausing the video repeatedly to help students focus on specific wordings realizing Jobs' life events, aiding students to identify and highlight those key wordings in the transcript from the spoken text. For Joint retelling, Mr. Noel used a timeline to revise the purpose and key wordings of this text and guide the joint retelling of the video. During Individual retelling, the students retold Jobs' life events using their previous notes and teacher's cueing through the timeline.

For Joint Construction, Mr. Noel and the students co-constructed the biography of the Colombian Vallenato singer, Martín Elías, using a timeline to annotate key wordings associated with the singer's life events. Afterwards, they jointly told Martín Elías' biography using the timeline as a scaffolding tool. During the independent speaking stage, Mr. Noel asked students to work in dyads to construct a timeline diagram and present the biography of a famous celebrity in front of the class.

\section{Data Collection and Analysis}

Data sources included four audio recordings and two video and audio-recorded lesson observations lasting 90 minutes each on average, as well as the production tasks of six students (three tasks before the implementation and another three at the end). Classroom observations served to document $\mathrm{Mr}$. Noel's implementation of the R2L cycle and students' responses to this model. Whereas the first three production tasks helped researchers gain an 
initial understanding of the students' linguistic resources and schematic structure for biographical recounts, the other three provided insights about variations in students' linguistic choices and meaning-making after R2L.

To identify the changes in students' oral production of biographical recounts, we analyzed the schematic structure, average units of meaning, and lexico-grammatical resources of three students' spoken biographical recounts presented individually at the beginning of the study and three more recounts students performed in pairs at the end. The schematic structure analysis involved the identification of the typical stages and phases of a biographical recount (Rose, 2018). The units of meaning analysis followed Halliday and Matthiessen's (2004) position that each clause construes a figure of meaning providing new content. For their identification, we considered utterances that contained a verb or process (Thompson, 2013) or provided new information despite not having a verb (e.g., "no children") in each one of the students' texts. Repeated utterances or students' self-correction were counted as a single clause.

Analysis of lexico-grammatical resources focused on the identification of transitivity elements (Thompson, 2013), namely participants (e.g., actor), processes (e.g., material, verbal, mental, etc.), and circumstances (e.g., time, manner), and their roles in each clause.

To understand the teacher's use of metalinguistic knowledge and its contribution to students' understanding and production of spoken recounts, we focused on how the teacher used the metalinguistic concept of stages and phases of a text as a tool to scaffold students' spoken meaningmaking throughout the different stages of the R2L cycle for spoken discourse. We first identified all moments in lessons in which the teacher used metalanguage, coding whether it was used verbally by the teacher or students, or whether it appeared represented in the form of a diagram (i.e., as a biographical timeline). Microanalysis of interaction (Wertsch, 1985) followed the coding stage in order to describe the roles of such metalinguistic knowledge in facilitating students' meaning-making in the various tasks of the R2L lessons. Qualitative analysis of these episodes was shared and discussed among researchers before arriving at interpretations.

\section{Findings}

Findings suggest that, towards the end of the R2L lessons, students became able to tell the life stages of famous people by following the schematic structure of biographical recounts and using more varied linguistic resources, which resulted in richer meaning-making. Below, we discuss these findings and describe how the teacher used metalinguistic knowledge, presented both verbally and visually as a pedagogical diagram, to scaffold students' meaning-making.

\section{Using the Genre's Schematic Structure to Produce Biographical Recounts}

Analysis revealed that students became able to organize their texts following the typical stages (orientation and life stages) and phases (e.g., early life, fame stages) of a biographical recount (Rose, 2018), including new phases that varied according to each celebrity's life. Table 1 illustrates the stages and phases of students' initial and final texts, including the number of clauses for each (e.g., X2 stands for two clauses).

Analysis of the phases conducted in students' biographical recounts also revealed that students became able to represent an increased variety of life events towards the end of the R2L lessons. As Table 1 shows, initial students' texts ${ }^{1}$ only included phases related to the orientation stage of a biographical recount. For instance, Mario's text about Neymar contained an initial phase indicating his

1 Square brackets indicate pronunciation errors, double parentheses show missing information; successive colons indicate lengthening of preceding phoneme. 
Table 1 Schematic Structure of Students' Biographical Recounts

\begin{tabular}{|c|c|c|c|c|c|c|c|}
\hline \multirow[b]{2}{*}{ Stage } & \multirow[b]{2}{*}{ Phase } & \multicolumn{3}{|c|}{ Initial Biographical recount } & \multicolumn{3}{|c|}{ Final Biographical recount } \\
\hline & & $\begin{array}{l}\text { Bonny's } \\
\text { text }\end{array}$ & $\begin{array}{l}\text { Mario's } \\
\text { text }\end{array}$ & $\begin{array}{l}\text { Vale's } \\
\text { text }\end{array}$ & $\begin{array}{l}\text { Bonny \& } \\
\text { Wendy's } \\
\text { text }\end{array}$ & $\begin{array}{l}\text { Mario \& } \\
\text { Jose's } \\
\text { text }\end{array}$ & $\begin{array}{l}\text { Vale \& } \\
\text { Yesi's } \\
\text { text }\end{array}$ \\
\hline \multirow{2}{*}{ Orientation } & Identifying the person & $X 4$ & $\times 3$ & $\times 3$ & $x$ & $x$ & $x$ \\
\hline & Birth & $x 2$ & $\mathrm{X} 2$ & X2 & $x$ & $\times 2$ & $x$ \\
\hline \multirow{8}{*}{ Life stages } & Childhood & $\ldots$ & $\cdots$ & $\ldots$ & $\ldots$ & $x$ & $\ldots$ \\
\hline & School & $\ldots$ & $\ldots$ & $\ldots$ & $\ldots$ & $x$ & $\ldots$ \\
\hline & Work & $\ldots$ & $\ldots$ & $\ldots$ & X4 & $\ldots$ & $\ldots$ \\
\hline & Marriage & $\ldots$ & $\ldots$ & $\ldots$ & $\ldots$ & $x$ & $x$ \\
\hline & Children's birth & $\ldots$ & $\ldots$ & $\ldots$ & $\ldots$ & $x$ & $\ldots$ \\
\hline & Divorce & $\ldots$ & $\ldots$ & $\ldots$ & $\ldots$ & $x$ & $\ldots$ \\
\hline & Fame & $\ldots$ & $\ldots$ & $\ldots$ & $x$ & $\ldots$ & $x$ \\
\hline & Death & $\ldots$ & $\ldots$ & $\ldots$ & $\times 3$ & $x$ & $x$ \\
\hline
\end{tabular}

Note: $\mathrm{X}=$ number of clauses in each phase, $\ldots=$ no clauses in the phase.

name (He is Neymar Silva Santos), his age (he is 30) and his profession (bis job a play soccer). The second phase included Neymar's date and place of birth ([Date of birth] 5 of [February]::: ((1992)), [Date of place] ((Mogi das Cruces)) Brazil). Bonny and Vale's texts included the same stage (orientation) and phases (person's name and date of birth) identified in Mario's text.

The students' final texts contained the two typical stages of biographical recounts (e.g., orientation and life events) as well as a variety of phases (birth, childhood, school, marriage, death) that signaled different events in the celebrities' lives. For instance, Mario and his partner Jose's final text included phases related to princess Diana's life events such as childhood (herparents divorced), school (she first time in school in September first 1970), marriage (his get [married] with [prince] Charles), children's birth (had his first [child] and second [child]), divorce (Diana and Charles divorced), and death (princess Diana dead in Paris, She died in Paris). Likewise, their partners' texts included varied phases that included marriage (Maria Teresa was (,1) his ? wife esposa, wife), fame (leader of the patriory [society]), and death (He ::: died 18[30]) along with remarkable life events of their chosen celebrities.
In sum, findings indicate that students' final texts included the typical stages of the biographical recount genre and a rich variety of phases according to each person's life experience. This may suggest that students gained awareness of the schematic structure of the biographical recount at the end of the R2L adapted cycle.

\section{Students' Use of Transitivity Resources}

Analysis of initial and final texts revealed that students conveyed more meanings using more varied transitivity resources in their spoken biographical recounts towards the end of the R2L lessons. Students' initial texts included an average of five units of meaning and transitivity resources such as relational processes, participants as value, carrier and attribute, and a few circumstances of time and place. In contrast, students' final texts included an average of nine units of meaning along with a greater number and variety of transitivity resources such as new participant roles, processes, and circumstances. This comparison is illustrated in Table 2.

Table 2 details students' use of units of meaning and transitivity resources in their texts. The units of meanings increased by almost four mean 
Table 2 Units of Meaning and Transitivity in Students' Spoken Biographical Recounts

\begin{tabular}{|c|c|c|c|c|c|c|c|c|}
\hline & \multicolumn{3}{|c|}{ Initial Texts } & \multirow[t]{2}{*}{ Mean } & \multicolumn{3}{|c|}{ Final Texts } & \multirow[t]{2}{*}{ Mean } \\
\hline & Mario's & Bonny's & Vale's & & $\begin{array}{l}\text { Mario \& } \\
\text { Jose's }\end{array}$ & $\begin{array}{l}\text { Bonny \& } \\
\text { Wendy's }\end{array}$ & $\begin{array}{l}\text { Vale \& } \\
\text { Yesi's }\end{array}$ & \\
\hline Units of meaning & 6 & 5 & 5 & 5.3 & 11 & 9 & 7 & 9 \\
\hline \multicolumn{9}{|l|}{ Participants } \\
\hline Value & 1 & 1 & 2 & 1.3 & 2 & 1 & 1 & 1.3 \\
\hline Carrier & 4 & 2 & 2 & 2.7 & 2 & 2 & 2 & 2.0 \\
\hline Attribute & 4 & 2 & 2 & 2.7 & 2 & 1 & 2 & 1.7 \\
\hline Actor & 0 & 0 & 0 & 0.0 & 5 & 6 & 1 & 4.0 \\
\hline \multicolumn{9}{|l|}{ Processes } \\
\hline Material & 0 & 0 & 0 & 0.0 & 7 & 5 & 2 & 4.7 \\
\hline Relational & 6 & 2 & 5 & 4.3 & 3 & 3 & 3 & 3.0 \\
\hline \multicolumn{9}{|l|}{ Circumstances } \\
\hline Time & 1 & 1 & 1 & 1.0 & 4 & 2 & 4 & 3.3 \\
\hline Place & 2 & 1 & 1 & 1.3 & 3 & 3 & 1 & 2.3 \\
\hline Role & 1 & 0 & 0 & 0.3 & 1 & 0 & 0 & 0.3 \\
\hline Accompaniment & 0 & 0 & 0 & 0.0 & 2 & 1 & 0 & 1.0 \\
\hline
\end{tabular}

points, specifically each case used between two and four more clauses containing new information in their final texts. This contrast can also be observed in Bonny and her partner's texts in Tables 3 and 4. Specifically Bonny's initial text (Table 3 ) contained six units of meaning. The first two units and the last one identify who Benito is (name, age, and occupation), whereas the other three units give information about his birth (birthdate and place of birth). Bonny and Wendy's final text contains eleven units of meaning. The students were able to tell the orientation in Clause 1 (name) as well as life events in Clauses 2 to 11 (birth, professional debut, signing of first international contract, obtention of first international prize, cerebral accident that caused death, and death). This points to a clear expansion of meaning potential throughout the R2L sessions, as students appear to have become able to produce a larger number of clauses conveying new content.

Regarding changes in students' use of transitivity resources, the number of clause participants as value, attribute, and carrier did not have significant differences; however, the number of participants as actors increased four mean points. Regarding processes, the number of relational processes decreased one mean point while the number of material processes increased almost five mean points. The number of circumstances also increased in the final texts; specifically, time circumstances increased two mean points while circumstances of place and accompaniment increased one mean point each. However, the number of role circumstances did not vary.

Students' use of these transitivity resources is further illustrated by qualitatively comparing students' initial and final spoken biographical recounts in Tables 3 and 4. For example, Bonny's initial text included human participants in relational clauses with only two circumstances of place and time, realizing the orientation stage of spoken biographical recounts (in Table 3, students' pronunciation mistakes have been omitted to facilitate reading).

As presented in Table 3, Bonny's text specifically contained the participant he as value in Clause 1 ( He is Benito Antonio Martinez Ocaso) and as carrier in Clauses 2 to 6 (he is twenty-three), as well as several attributes (e.g., twenty-three, a singer). In Clause 1, the relational process be performed an Identifying 
Table 3 Benito's biography by Bonny

\begin{tabular}{lllll}
\hline 1 & $H e$ & is & Benito Antonio Martinez Ocaso & \\
\cline { 2 - 5 } & Part:Value & Rel: Identifying & Token & \\
\hline 2 & $H e$ & is & twenty-three & \\
\cline { 2 - 5 } & Part:Carrier:Human & Rel:identifying & Part:Attribute & of twenty-six of March 1994 \\
\hline 3 & He & is & born & Circ: time \\
\cline { 2 - 5 } & Part:Carrier:Human & Rel:Attributive & Part:Attribute & in San Juan Puerto Rico \\
\hline 4 & He & is & born & Circ: place \\
\cline { 2 - 5 } & Part:Carrier:Human & Rel:Attributive & Part:Attribute & \\
\hline 5 & He & is & from San Juan de Puerto Rico, Estados Unidos & \\
\cline { 2 - 5 } & Part:Carrier:Human & Rel:Attributive & Part:Attribute & \\
\hline 6 & He & is & a singer & \\
\cline { 2 - 5 } & Part:Carrier:Human & Rel:Attributive & Part:Attribute & \\
\hline
\end{tabular}

Note Part $=$ participant, Rel $=$ relational process, Circ $=$ circumstance

function; in Clauses 2 to 6, its function was Attributive, describing the person's age, birth, profession, and nationality. Bonny's text included only two circumstances, one of time in Clause 3 (He is born of twenty-six of March 1994) and one of place in Clause 4 (He is from San Juan de Puerto Rico). Although Bonny's use of these linguistic resources allowed her to introduce the character of her biography, they seemed insufficient to achieve the distinctive purpose of a biographical recount, which is to narrate the life events of a person.

In contrast, Bonny \& Wendy's final text (Table 4) included a greater variety of units of meaning and transitivity resources. This allowed them to retell important events in a person's biography, therefore achieving the purpose and following the stages and phases of a biographical recount. These resources included both relational and material clauses with participants (i.e., the celebrities) as actors, a variety of which was missing in the initial texts.

Bonny and Wendy's text included eleven clauses, four of which were relational. Clauses 1 and 2 were of the identifying type (He is Miguel Calero), whereas Clauses 3 and 10 were attributive (He was born in 1971). These clauses included participants as value, carrier and attribute, and one circumstance of time (in 1971). Clauses 4 to 7 contained four material: intentional processes (e.g., he debuted); Clause 8 contained a passive: material process (e.g., he was taken), and Clauses 9 and 11 contained material: involuntary processes (e.g., he died).

New participant roles appeared in the text such as actor, in Clauses 4 to 7 and 9 to 11 (e.g., he first obtained the Mexican title) and goal in clause 8 (e.g., Calero was taken to emergency). Students included varied circumstances such as role (e.g., as professional player) and accompaniment (e.g., with Pachuca, with cerebral thrombosis) in Clauses 4, 6, 7, and 8; time (e.g., in 14 of April, in December $4^{\text {th }}$ 2012) in Clauses 2, 3, 8, and 11; and place (e.g., in Barranquilla, in Mexico, to emergency) in Clauses $5,6,8$, and 9. A combination of circumstances is also observed in the sixth and eighth clauses where students specified role and place (e.g., with Pachuca in Mexico), and place, accompaniment, and time (e.g., to emergency in a day of Sunday noviembre 25 with a cerebral thrombosis), respectively.

In sum, the increased number in units of meaning as well as the greater variety of transitivity resources in students' final spoken biographical recounts may provide important evidence of the students' expanded meaning-making potential by the end of the R2L lessons. Such increased potential allowed students to achieve the distinctive purpose of biographical recounts, which is to narrate the main events of a person's life. In other words, learners' meaning-making 
Table 4 Calero's Biography by Bonny \& Wendy

\begin{tabular}{|c|c|c|c|c|c|}
\hline \multirow[t]{2}{*}{1} & he & is & \multicolumn{3}{|l|}{ Miguel Calero } \\
\hline & Part:Value & Rel: Identifying & Token & & \\
\hline \multirow{2}{*}{2} & his birth & was & in 14 of April, & & \\
\hline & $\begin{array}{l}\text { Part:Value: } \\
\text { Non-Human }\end{array}$ & Rel: Identifying & Circumst: Time & & \\
\hline \multirow[t]{2}{*}{3} & he & was & born & in 1971 & \\
\hline & Part:Carrier: Human & Rel: Attributive & Attribute & Circumst: Time & \\
\hline \multirow[t]{2}{*}{4} & he & debuted & as profession player & & \\
\hline & Part:Actor: Human & Mat:Intentional & Circumst: Role & & \\
\hline \multirow[t]{2}{*}{5} & -- & started & in Barranquilla, Colombia, & & \\
\hline & Part:Actor: Human & Mat:Intentional & Circumst: Place & & \\
\hline \multirow[t]{2}{*}{6} & he & signed & his main contract & with Pachuca & in Mexico \\
\hline & Part:Actor: Human & Mat:Intentional & Goal & Circumst: Accomp & Circumst: Place \\
\hline \multirow{2}{*}{7} & he & first & obtained & the Mexican title & versus Tigre de UaNL \\
\hline & Part:Actor: Human & & Mat:intentional & Goal & Circumst: Accomp \\
\hline \multirow[t]{2}{*}{8} & Calero & was taken & to emergency & $\begin{array}{l}\text { in a day of Sunday } \\
\text { noviembre } 25\end{array}$ & $\begin{array}{l}\text { with a cerebral } \\
\text { thrombosis }\end{array}$ \\
\hline & Part:Goal & Mat:Passive & Circumst: Place & Circumst: Time & Circumst: Accomp \\
\hline \multirow[t]{2}{*}{9} & and he & died & in Mexico city & & \\
\hline & Part:Actor: Human & Mat:Involuntary & Circumst: Place & & \\
\hline \multirow[t]{2}{*}{10} & He & was & 41 years old & & \\
\hline & Part:Carrier: Human & Rel: Attributive & Attribute & & \\
\hline \multirow[t]{2}{*}{11} & $\mathrm{He}$ & died & in December $4^{\text {th }} 2012$ & & \\
\hline & Part:Actor: Human & Mat: Involuntary & Circumst: Time & & \\
\hline
\end{tabular}

Note Part $=$ participant, Mat $=$ material process, Rel $=$ relational process, Circumst $=$ circumstance, Accomp $=$ accompaniment.

potential went from simply introducing the person whose life events they would describe to both introducing the person and recounting his/her life events using a greater variety of linguistic resources during the R2L lessons.

\section{Scaffolding Spoken Discourse Through \\ Metalanguage and Pedagogical Diagrams}

This section describes how Mr. Noel used metalinguistic knowledge of stages and phases of a text as a tool to scaffold learners' attempts to tell biographical recounts in the R2L lessons. This tool appeared first verbally, in Mr. Noel's explanations during preparing for listening, detailed listening, and joint retelling (Lessons 1 and 2), and then as a diagram in the form of a biographical timeline that students used to prepare for individual retelling, joint construction, and independent speaking (Lessons 2 through 4 ).

Metalinguistic support of learners' understanding and reporting of a spoken biographical recount

Metalinguistic knowledge of stages of a text first appeared verbally, in Mr. Noel's interaction with 


\begin{tabular}{|c|c|c|c|}
\hline 1 & $\mathrm{~T}$ & Vamos a ver un video, de la vida de $\underline{\text { Steve Jobs }}$ & Let's watch a video, about Steve Jobs' life \\
\hline 2 & S? & Steve Jobs & \\
\hline 3 & $\mathrm{~T}$ & $\begin{array}{l}\text { Una biografía, y nos van a contar un poquito acerca } \\
\text { de su::: nacimiento, Atentos aca por favor, nos van a } \\
\text { contar un poquito acerca de su nacimiento, his BIRTH, } \\
\text { recuerdan BIRTH? }\end{array}$ & $\begin{array}{l}\text { A biography and it will tell us a little about his::: birth, } \\
\text { pay attention please, it will tell us a little bit about his } \\
\text { birth, his BIRTH, remember, BIRTH? }\end{array}$ \\
\hline & S? & Uh huh & \\
\hline & $\mathrm{T}$ & $\begin{array}{l}\text { ¿verdad? Nacimiento, nos van a contar un poquito } \\
\text { acerca de sus::: primeros trabajos de su vida en la } \\
\text { universidad::: nos va a contar un poquito acerca de?, } \\
\text { Eh:: }\end{array}$ & $\begin{array}{l}\text { Right? Birth, it will tells us a little bit about his::: first } \\
\text { jobs, his life in college::: it will tell us a little bit about?, } \\
\text { Eh::: }\end{array}$ \\
\hline 4 & S? & Y que estudió él, profe? & And what did he study, prof? \\
\hline 5 & $\mathrm{~T}$ & $\begin{array}{l}\text { (.2) esa es una muy buena pregunta, su familia::: los } \\
\text { amigos::: verdad? Nos van a contar, de todo eso, pero no } \\
\text { nos van a decir hacer- no nos van a hablar de la fecha } \\
\text { de cuando falleció por eso que, era importante que } \\
\text { revisaran verdad? Entonces vamos a estar atentos al } \\
\text { video eh, y eh bueno, vamos a prestar atención al video }\end{array}$ & $\begin{array}{l}\text { (.2) that's a really good question, his family::his } \\
\text { friends:::right? It will tell us a little bit about all that, } \\
\text { but it won't tell us, it won't tell us the date when he died } \\
\text { because it was important that you check, right? So, we } \\
\text { are going to pay attention to the video eh, and eh well, } \\
\text { we are going to pay attention to the video }\end{array}$ \\
\hline
\end{tabular}

Figure 2 Mr. Noel's Use of Verbal Metalinguistic Support (transcript 1)

learners, to support understanding and retelling of a biographical recount of Steve Job's life. Transcript 1 (see Figure 2) occurred after Mr. Noel brainstormed students' previous knowledge of Steve Jobs at the beginning of the first lesson. Mr. Noel stood in front of the class while the video of Steve Job's life was projected on the board.

Mr. Noel used the metalinguistic term 'biography' (Turn 3) and referred to the contents of the video in terms of the stages of Steve Job's life, such as birth, first jobs, university life (Turn 3), and family and friends (Turn 5). Such preview of the contents of the video intended to facilitate understanding by offering students a sequence of events they could use to guide their listening and watching of the video.

Verbal support about the stages of a text also occurred as shared metalanguage that Mr. Noel and students used in their interactions towards the end of the first lesson. Unlike Transcript 1, such support facilitated students' active engagement in reporting their understanding of the video. Transcript 2 (see Figure 3) occurred after detailed listening and highlighting of key wordings in a written version of Steve Jobs' video, at the end of the first lesson. The video was paused but projected on the board.

Similarly to Transcript 1 (Figure 2), Mr. Noel's use of the idea of stages provided a framework for students to report their understanding of the video. Unlike Transcript 1, however, metalinguistic terms appeared both in students and Mr. Noel's talk as a metalinguistic tool for naming the stages of Steve Job's life (Turns 2, 4, 6, 8, and 9) and to refer to the contents of the video more generally ("stages," Turn 1).

In addition to using metalanguage verbally, during the second lesson Mr. Noel represented it as a timeline. This timeline functioned as a Pedagogical Diagram (Martin \& Rose, 2008) that organized 


\begin{tabular}{|llll|}
\hline 1 & T & $\begin{array}{l}\text { Qué etapas de la vida de Steve podemos identificar } \\
\text { aquí, a ver? ((referring to transcript)) }\end{array}$ & Which stages of Steve Job's life can we identify here, let's see? \\
2 & S1 & La infancia & Infancy \\
3 & T & Okay::: & Adolescence \\
4 & S? & la adolescencia & We can go \\
5 & T & podemos irlo ((writes Birth on the whiteboard)) BIRTH & Birth \\
6 & S? & Nacimiento & Okay, what else does it talk about, let's see? \\
7 & T & okay, de que más nos hablan acá a ver? ((referring & \\
& & to transcript)), what else? & Childhood \\
8 & S1 & La niñez & Infancy \\
9 & S? & La infancia & \\
10 & T & Okay::: ((writes childhood on the whiteboard)) & About his studies \\
11 & S3 & De su estudio & Life stages \\
12 & S1 & ((addressing S3)) Etapas de la vida & Adolescence \\
13 & S2 & la adolescencia (.2) adolescense & \\
14 & T & ADoLescence ((writes adolescence on the board)) &
\end{tabular}

Figure 3 Metalinguistic Support as Shared Metalanguage (transcript 2)

the joint retelling of Steve Jobs' biography. Mr. Noel drew the timeline from top to bottom on the left of the board. The timeline included the phrase "Steve Jobs Biography" as title and the words "birth," "school years," "college," and "work," written one below the other along an arrow-tipped line. Mr. Noel and students had also written notes consisting of phrases and a few sentences to summarize the stages of Jobs' life on the right of the board. To also provide support, Mr. Noel projected the video in the center of the board, without sound, and stopped it after each key stage in Steve Job's life. The phrase Reed College was one of the notes written on the right of the whiteboard. Transcript 3 (Figure 4) shows a clear example of how Mr. Noel used metalinguistic support in the form of a timeline for guiding joint retelling of Jobs' life.

While previous verbal uses of metalanguage had facilitated understanding of the video, the diagram representing the stages of Steve Jobs' life facilitated students' speaking, albeit in retelling under $\mathrm{Mr}$. Noel's direction. Students first identified the stage they would talk about (Turns 2 and 4) and then provided information about it supported by Mr. Noel's continuous prompting (Turns 5, 7, 9, and 11). It is revealing how the timeline, along with the notes and the muted video, was material in facilitating students towards what to say, also offering opportunities for Mr. Noel to clarify content (Turns 13 to 21) and emphasize the kind of lexicogrammar (Turns 23 and 25) students would need for joint construction and independent speaking in later lessons.

\section{The Timeline as a Pedagogical Diagram to Scaffold Joint and Independent Construction of a Spoken Text}

The timeline also worked as a pedagogical diagram that students used to guide their EFL spoken meaningmaking. Students first annotated key wordings in the timeline and then used those wordings during both joint construction and independent speaking. As preparation for joint construction students looked for information about Martín Elías, a famous Colombian singer whose biography students had chosen to tell. Then, during the third lesson, Mr. Noel drew another timeline horizontally along the 
whiteboard. Students and Mr. Noel used the timeline to brainstorm details about Martin Elias' life, which they then annotated on the board. Transcript 4 (Figure 5) illustrates how students and Mr. Noel jointly constructed the stages in Martin Elias' biography using the timeline as visual metalinguistic support. The word "no" was the only note written under the stage "college" in the timeline.

Mr. Noel tapped on the timeline (Turn 1) to direct students' speaking towards the stage of "college" in Martin Elias biography. Then, as S1 started to speak, he provided support by repeating $S 1$ 's contribution with rising intonation (Turns 5, 8, and 12) and making clarifications about the content of this stage (Turn 10). It is revealing in Transcript 4 how $S 1$ became able to build a full clause from the note "No" in the timeline, showing in turn how the timeline's and Mr. Noel's support facilitated S1's precise and grammatically accurate description of this stage in Martin Elias' life (Turns 11 and 13).

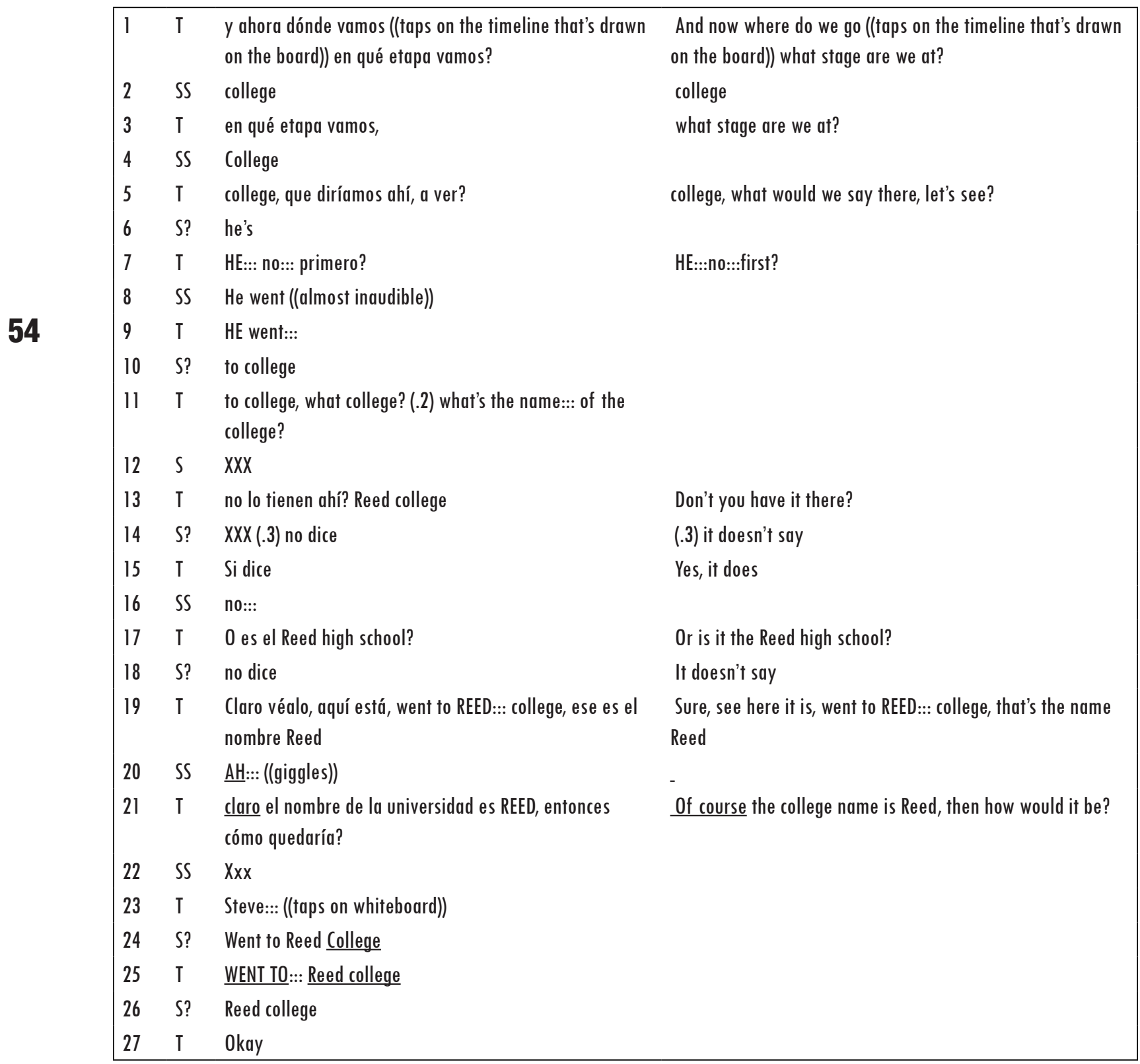

Figure 4 Metalinguistic Support in the Form of a Timeline (transcript 3) 


\begin{tabular}{|c|c|c|c|}
\hline 1 & $\mathrm{~T}$ & $\begin{array}{l}\text { College ((taps whiteboard with the marker on the word } \\
\text { college in the timeline)) }\end{array}$ & \\
\hline 2 & SI & No (.3) He & \\
\hline 3 & $\mathrm{~T}$ & He:: & \\
\hline 4 & SS & He didn’t & \\
\hline 5 & $\mathrm{~T}$ & He didn't? & \\
\hline 6 & SI & A college & - \\
\hline 7 & S2 & graduate graduate & - \\
\hline 8 & $\mathrm{~T}$ & He didn't? (.2) & \\
\hline 9 & S2 & Graduate No se graduó & He didn't graduate \\
\hline 10 & $\mathrm{~T}$ & $\begin{array}{l}\text { Ok, no se graduó, pero es que ni siquiera empezó. Como } \\
\text { diríamos entonces? }\end{array}$ & $\begin{array}{l}\text { Ok, he didn't graduate, but he didn't even start. How would we } \\
\text { say, then? }\end{array}$ \\
\hline 11 & SI & He didn't:: & \\
\hline 12 & $\mathrm{~T}$ & He didn't? & \\
\hline 13 & SI & Go to college & \\
\hline 14 & $\mathrm{~T}$ & Go to college. Right, he DIDN'T go to college. & \\
\hline
\end{tabular}

Figure 5 Visual metalinguistic support of joint construction (transcript 4)

In the final lesson students used the timeline on their own, in small groups, as a visual support tool to tell their biographies independently. As preparation for independent speaking, $\mathrm{Mr}$. Noel distributed written biographies of three famous characters students had chosen in the previous lesson: Miguel Calero (a Colombian soccer player), Simón Bolivar (a military leader during Colombian independence), and Princess Diana of Wales (the late princess of England). In small groups, students drew timelines in their notebooks and took notes about the life stages of the character whose biography they had decided to tell. Mr. Noel interacted with the small groups to help them with pronunciation, lexicogrammar, and understanding the written biographies. Figure 6, about Princess Diana's biography, is one example of the timelines each group drew and the kind of notes they took.

The picture shows students' notes of key events in Diana's life. Some of the notes consisted of abridged information, realized by circumstances of time (e.g., Diana's date of birth or the start of her schooling), while others included verb processes (e.g., divorced, died, or get married) or larger segments of text (e.g., get married with Prince Charles). Transcript 5 (Figure 7) shows Mario's attempts to recount the details of Diana's birth independently, using both the timeline and teacher prompts as support.

Mario started by identifying Princess Diana as the topic of his biography (Turn 1). The fact that this was not specified in the timeline shows Mario's ability to fulfill this part of the orientation stage of biographical recounts independently. Mario's recount of Diana's birth is especially revealing of the role of the timeline in scaffolding students' spoken meaning-making. Mario used the prompt "birth" in the timeline to start his recount, to which Mr. Noel provided implicit support (Turns 4 and 6) and then the pronoun (Turn 8) as a starter for Mario's talk. This allowed Mario to recount the details of Diana's birth with the clause "she was born in first July 1969 in Wales." The fact that Mr. Noel's support between turns 14 and 20 occurred simultaneously as Mario's talk (shown by the underlined segments) indicates that such support may not have been necessary for Mario to complete his 


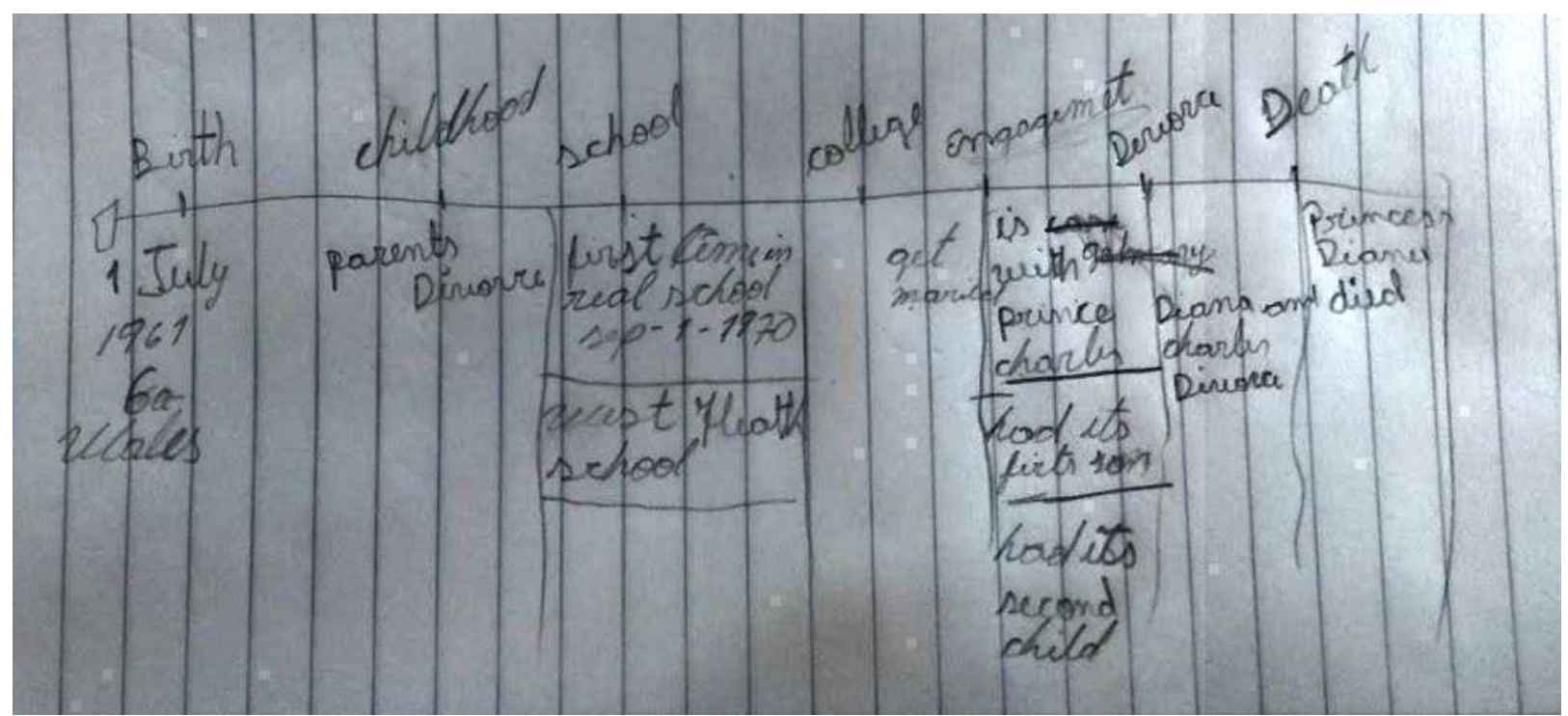

Figure 6 Picture of a Student's Timeline of Princess Diana’s Biography

intended meanings. A similar pattern of timelineteacher support occurred during the rest of Mario's recount of Diana's life up to her schooling. For the rest of the biographical recount, Mario's partner, cates his limited potential to retell the stages of Diana's life independently. As we will discuss in the next section, the combination of visual metalinguistic support condensed in the timeline and Mr. Noel's prompting was material for engaging students such as Mario in purposeful and relatively independent meaning-making.

\section{Discussion and Conclusions}

This study investigated how a teacher's use of R2L during four lessons facilitated EFL learners' ability to tell biographical recounts in English. While extensive research has shown quite compellingly that genre-based pedagogyserves toimprove reading and writing at the school level (see Schleppegrell, 2017 for a recent review), this study revealed that R2L pedagogy may also contribute to develop EFL students' spoken meaning potential. Findings indicated that learners incorporated more stages and phases to their texts, using a greater number of verbal processes, participants, and circumstances to realize a larger number of spoken clauses

including new content. Although we compared only six students' texts over four lessons, three of which were produced by dyads, results suggest that $\mathrm{R} 2 \mathrm{~L}$ may be a promising approach to promote learners' spoken meaning-making in EFL contexts. Further and more longitudinal research is sorely needed that investigates the uses of R2L and other genre-based models to improve spoken meaning-making in a greater variety of genres and curricular contexts.

The increase in students' meaning-making resources notwithstanding, findings also revealed that the four R2L lessons may have been insufficient to help all learners do a totally independent spoken recount. Indeed, while students such as Mario needed only a few abridged notes in the timeline and Mr. Noel's encouragement to be able to recount Princess Diana's biography using appropriate lexicogrammar, others like José simply read from the timeline, failing thus to tell their recount independently. One lesson to be learned from this is that transitioning from joint to independent construction may not be as smooth or straightforward as the genre-based model seems to imply (see also Wilkins, 2018 for a similar comment). Especially in spoken discourse where the production of texts occurs online (i.e., without the chance to draft or edit the text in advance to its 


\begin{tabular}{|llll|}
\hline 1 & M & She is prince Diana & Uhuh \\
2 & T & Aja & \\
3 & M & Eh [birth] & I got confused, \\
4 & T & Ah? & \\
5 & M & Me confundí, Bir- [birth] in & I forgot, eh, how do you say? \\
6 & T & Ah? Birth? & What would we say? \\
7 & M & Se me olvidó, eh, cómo se dice? & \\
8 & T & Qué diríamos? (.2) she:: & Uhuh? \\
9 & M & She birth she born no she was & \\
10 & T & Aja? & eh how do you say nineteen? \\
11 & M & [born] & \\
12 & T & She was born & \\
13 & M & Born in first July eh como se dice diecinueve? & Uhuh \\
14 & T & Nineteen & In Wales \\
15 & M & Nineteen sixty-one & \\
16 & T & Sixty-one aja where? & On Wales \\
17 & M & In Gales & \\
18 & T & She was born in & Uhuh \\
19 & M & She was born on Gales & Wales \\
20 & T & In Wales & \\
21 & M & Aja & \\
22 & T & & \\
\hline
\end{tabular}

Figure 7 The Timeline as a Visual Metalinguistic Tool During Independent Speaking (transcript 5)

production), additional scaffolding tools may be needed that provide support to learners' attempts to create spoken meaning without teacher support. We argue that pedagogical diagrams such as the timeline Mr. Noel used may provide such kind of intermediate support between joint and independent construction in genre-based lessons. The use of pedagogical diagrams to mediate learning and development is an intriguing area of sociocultural, concept-based research (Arievitch \& Haenen, 2005; Herazo, 2014; Karpov, 2018) that has potential to inform future genre-based studies.

This study also revealed that the metalinguistic knowledge that a biographical recount develops in stages over time, which Mr. Noel presented to learners in his explanations and in the timeline, was consequential to improving learners' spoken discourse. Recent research has emphasized the importance of such knowledge during genrebased lessons, arguing that it leads to increasing genre awareness (Humphrey \& Feez, 2016; Schleppegrell, 2013; Yasuda, 2011) and developing student thinking (Gánem-Gutiérrez \& Roehr, 2011; Herazo, 2021) in ways that favor independent meaning-making. What seems intriguing in our findings, however, is how the teacher combined a verbal realization of metalinguistic knowledge with a visual representation of it to purposefully hand over responsibility to learners 
so that they could make meaning independently. Unfortunately, attention to such multimodal combination of support during classroom interaction seems to be missing in most genre-based research (Schleppegrell, 2013, 2017). Further research is needed that pays attention to how various semiotics resources (i.e., gesture, gaze, proxemics, visual representations) combine during classroom interaction in genre-based lessons so as to ensure independent meaning-making. More specifically, future R2L studies could draw from Systemic Functional Multimodal Discourse Analysis (Jewitt et al., 2016; O’Toole, 2011), multiliteracies (Early et al., 2015), and multimodal empirical scholarship (see, for example, Taleghani-Nikazm, 2015; Shin et al., 2020) to inform analyses of L2 classroom interaction in genre-based research.

This study has shown how a teacher used R2L to promote spoken meaning-making in an EFL classroom, weaving both verbal and a more visual representations of metalinguisticknowledge to scaffold students' ability to tell biographical recounts. To that end, the teacher adapted the stages of the $\mathrm{R} 2 \mathrm{~L}$ approach as he engaged learners in preparing for listening, detailed listening, joint retelling, spoken joint construction, and independent speaking through a series of four lessons. Although limited in the number of lessons, participants, and text corpus, this study offers insights into how teachers and future research studies can use genre-based models such as $\mathrm{R} 2 \mathrm{~L}$ to promote spoken meaningmaking in EFL classrooms.

\section{References}

Achugar, M. (2003). Academic registers in Spanish in the US: A study of oral texts produced by bilingual speakers in a university graduate program. In A. R. C. Colombi (Ed.), Mi lengua: Spanish as a heritage language in the United States (pp. 213-234). Georgetown University Press.

Achugar, M., \& Carpenter, B. D. (2012). Developing disciplinary literacy in a multilingual history classroom. Linguistics and Education, 23(3), 262-276. https:// doi.org/10.1016/j.linged.2012.05.003
Arievitch, I. M., \& Haenen, J. P. P. (2005). Connecting sociocultural theory and educational practice: Galperin's approach. Educational Psychologist, 40(3), 155-165. https://doi.org/10.1207/s15326985ep4003_2

Banks, P. (2000). Measuring student performance in casual conversation. In H. Joyce (Ed.), Teachers' voices 6. Teaching casual conversation. (pp. 1-100). Macquarie University.

Becerra, T., Herazo, J., García, P., Sagre, A., \& Díaz, L. (2019). Using reading to learn for EFL students' reading of explanations. ELT Journal, 3(74), 237246. https://doi.org/10.1093/elt/ccz053

Benedict, L. (2006). Genre-based teaching and Vygotskian principles in EFL: The case of a university writing course. Asian EFL Journal 8(3), 226-248. http:// asian-efl-journal.com/September_2006_EBook_ editions.pdf

Benítez, T., Barletta, N., Chamorro, D., Mizuno, J., \& Moss, G. (2018). Reading and writing across the curriculum. In A. Sellami-Baklouti \& L. Fontaine (Eds.), Perspectives from systemic functional linguistics $\left(4^{\text {th }}\right.$ Ed.), vol. 9, pp. 249-268. Routledge. https://doi. org/10.4324/9781315299877-13

Braun V., \& Clarke, V. (2006). Using thematic analysis in psychology. Qualitative Research in Psychology, 3(2), 77-101. https:// doi. org/10.1191/1478088706qp063oa

Brisk, M., \& de Rosa, M. (2014). Young writers' attempts at making meaning through complex sentence structures while writing a variety of genres. In L. de Oliveira \& J. Iddings (Eds.), Genre pedagogy across the curriculum (pp. 8-24). Equinox.

Byrnes, H., Maxim, H. H., \& Norris, J. M. (2010). Realizing advanced foreign language writing development in collegiate education: Curricular design, pedagogy, assessment. The Modern Language Journal, 94(1), 1-235. https://doi. org/10.1111/j.1540-4781.2010.01136.x

Christie, F. (2004). Systemic functional linguistics and a theory of language in education. Ilha do Desterro, 1(46), 13-40. https://doi.org/10.5007/\%25x

De Oliveira, L., \& Iddings, J. (2014). Genre pedagogy across the curriculum. Equinox.

Derewianka, B. (1990). Exploring how texts work. Primary English Teaching Association.

Derewianka, B. (2003). Trends and issues in genre-based approaches.RELCJournal,34(2),133-154.Continuum. https://doi.org/10.1177/003368820303400202 
Dreyfus, S., Humphrey, S., Mahboob, A., \& Martin, J. R. (2016). Genre pedagogy in higher education: The SLATE project. Palgrave Macmillan. https://doi. org/10.1007/978-1-137-31000-2

Early, M., Kendrick, M., \& Potts, D. (2015). Multimodality: Out from the margins of English language teaching. TESOL Quarterly, 3(49), 447-460. https://doi.org/10.1002/tesq.246

Fernandez, L. (2017). Learning another language with conceptual tools: An investigation of Gal'perin's concept-oriented instruction. (Unpublished doctoral dissertation). University of Pittsburgh. http://dscholarship.pitt.edu/32071/

Fernandez. L. \& Donato, R. (2020). Interacting with scoBAs: Beginner learners of foreign language use of a pedagogical tool. Language and Sociocultural Theory, 7(1).

Gánem-Gutiérrez, G. A., \& Roehr, K. (2011). Use of L1, metalanguage, and discourse markers: L2 learner' regulation during individual task performance. InternationalJournalof AppliedLinguistics, 21(3),297-318. https://doi.org/10.1111/j.1473-4192.2010.00274.x

Gebhard, M., Harman, R., \& Seger, W. (2007). Reclaiming recess: Learning the language of persuasion. Language Arts, 84(5), 419-430.

Gibbons, P. (2003). Mediating language learning: Teacher interactions with ESL students in a content-based classroom. TESOL Quarterly, 37(2), 247-273. https://doi.org/10.2307/3588504

Halliday, M. A. K. \& Matthiessen, C. (2004). An introduction to functional grammar $\left(3^{\text {rd }} \mathrm{Ed}\right.$.). Arnold.

Halliday, M. A. K. (1993). Towards a language-based theory of learning. Linguistics and Education, 5(2), 93-116. https://doi.org/10.1016/0898-5898(93)90026-7

Hasan, R. (2004). The concept of semiotic mediation: Perspectives from Bernstein's sociology. In B. Davies, J. Muller, \& A. Morais (Eds.), Reading Bernstein, researching Bernstein (pp. 48-61). Routledge Falmer.

Herazo, J. D. (2012). Using a genre-based approach to promote oral communication in the Colombian English classroom. Colombian Applied Linguistics Journal, 14(2), 109-126. https://doi.org/10.14483/udistrital.jour.calj.2012.2.a07

Herazo, J. D. (2014). Second language (L2) development as concept-mediated textual activity: Exploring the role of functional language concepts in classroom L2 communication and learning. (Unpublished Ph. D. dissertation). University of Pittsburgh.
Herazo, J. D. (2021). Mediating spoken meaning-making in genre-based lessons: The role of metalinguistic concepts. System, 96, 102398. https://doi.org/10.1016/j. system.2020.102398

Humphrey, S., \& Feez, S. (2016). Direct instruction fit for purpose: Applying a metalinguistic toolkit to enhance creative writing in the early secondary years. Australian Journal of Language \& Literacy 39(3), 207-219.

Humphrey, S., \& Macnaught, L. (2011). Revisiting joint construction in the tertiary context. Australian Journal of Language and Literacy 34(1), 98-114.

Jewitt, C., Bezemer, J., \& O’Halloran, K. (2016). Introducing multimodality. Routledge. https://doi. org/10.4324/9781315638027

Joyce, H. de S. \& Slade, D. (2000). The nature of casual conversation: Implications for teaching. In H. Joyce (Ed.), Teachers' voices 6: Teaching casual conversation. (pp. 1-100). Macquarie University. http:// www.ameprc.mq.edu.au/__data/assets/pdf_ file/0018/241533/Teachers_Voices_6.pdf

Karpov, Y. (2018). Acquisition of scientific concepts as the content of school instruction. In J. P. Lantolf, M. E. Poehner, \& M. Swain (Eds.), The Routledge handbook of sociocultural theory and second language development (pp. 102-116). Routledge.

Khatibi, M. B. (2014). The effect of genre-based teaching on EFL learners' speaking performance. Research in English Language Pedagogy, 2(1), 38-52.

Koop, C. \& Rose, D. (2008). Reading to learn in Murdi Paaki: Changing outcomes for Indigenous students. Literacy learning: The middle years, 16(1), 41-46.

Martin, J. R., Christie, F., \& Rothery, J. (1987). Social processes in education: A reply to Sawyer and Watson (and others). In I. Reid (Ed.), The place of genre in learning: Current debates (pp. 46-57). Deakin University Press.

Martin, J. R. \& D. Rose (2007). Interacting with text: the role of dialogue in learning to read and write. Foreign Languages in China 4(5), 66-80.

Martin, J. R. \& Rose, D. (2008). Genre relations: Mapping culture. Equinox.

McKay, P., Bowyer., L \& Commins, L. (2000). Teaching casual conversation for workplace communication. In H. Joyce (Ed.), Teachers' voices 6: Teaching casual conversation. (pp. 44-54). Macquarie University.

Millin, T. J. \& Millin, M. W. (2014). Scaffolding academic literacy using the Reading to Learn intervention: An evaluation study of a tertiary education context in 
South Africa. Per Linguam 30(3), 26-38. https:// doi.org/10.5785/30-3-590

O’Toole, M. (2004). Opera ludentes: The Sydney Opera House at work and play. In K. O'Halloran (Ed.), Multimodal discourse analysis: Systemic functional perspectives (pp. 11-27). Continuum.

Richards, K. (2003). Qualitative inquiry in $T E-$ SOL. Palgrave Macmillan. https://doi. org $/ 10.1057 / 9780230505056$

Rose, D. (2008). Teaching reading and writing to aboriginal children. In N. Harrison (ed.), Teaching and Learning in Indigenous Education. Oxford University Press.

Rose, D. (2015). Reading to Learn: Accelerating learning and closing the gap. Teacher training books and DVDs. http://www.readingtolearn.com.au

Rose, D. (2018). Languages of schooling: Embedding literacy learning with genre-based pedagogy. European Journal of Applied Linguistics, 6(1), 59-89. https:// doi.org/10.1515/eujal-2017-0008

Rose, D. \& J. R. Martin. (2012). Learning to write, reading to learn: Genre, knowledge and pedagogy in the Sydney School. Equinox.

Schleppegrell, M. J. (2004). The language of schooling: A functional linguistics perspective. Routledge. https:// doi.org/10.4324/9781410610317

Schleppegrell, M. (2013). The role of metalanguage in supporting academic language development. Language Learning, 63(s1), 153-170. https://doi. org/10.1111/j.1467-9922.2012.00742.x

Schleppegrell, M. (2017). Systemic functional grammar in the K-12 classroom. In E. Hinkel (Ed.), Handbook of research in second language teaching and learning (Vol. 3, pp. 384-396). Routledge.

Schleppegrell, M. J., Moore, J., Al-Adeimi, S., O'Hallaron, C., Palincsar, A., \& Symons, C. (2014). Tackling a genre: Situating SFL genre pedagogy in a new context. In L. Oliveira \& J. Iddings (Eds.), Genre pedagogy across curriculum (pp. 26-39). Virginia Military Institute.

Shin, D. S., Cimasko, T., \& Yi, Y. (2020). Development of metalanguage for multimodal composing: A case study of an L2 writer's design of multimedia texts. Journal of Second Language Writing, 47, 1-14, https://doi.org/10.1016/j.jslw.2020.100714

Taleghani-Nikazm, C. (2015). On multimodality and coordinated participation in second language interaction. Dialogue in Multilingual and Multimodal Communities, 27, 79-100. https://doi. org/10.1075/ds.27.03tal

Thompson, G.(2013).Introducingfunctionalgrammar. Routledge. https://doi.org/10.4324/9780203431474

Vygotsky, L. S. (1978). Mind in society: The development of higherpsychological processes. Harvard University Press.

Wertsch, J. V. (1985). Culture, communication, and cognition: Vygotskian perspectives. Cambridge University Press.

Whittaker, R. \& Acevedo, C. (2016). Working on literacy in CLIL/bilingual contexts: Reading to learn and teacher development. Estudios Sobre Educación, 31, 37-55. https://doi. org/10.15581/004.31.37-55

Whittaker, R., \& Lövstedt, A.-C. (2017). Un proyecto europeo para la mejora de competencias discursivas en Europa: Reading to learn en TeL4ELE. Lenguaje y Textos, 46, 29-39. https://doi. org/10.4995/lyt.2017.8712

Wilkins, G. (2018). A genre-based approach to speaking in EFL. (Unpublished Ph. D. dissertation). Aston University.

Yasuda, S. (2011). Genre-based tasks in foreign language writing: Developing writers' genre awareness, linguistic knowledge, and writing competence. Journal of Second Language Writing, 20(2), 111-133. https://doi.org/10.1016/j.jslw.2011.03.001

How to cite this article: Herazo, J. D.; Becerra, T.; García-Montes, P.; Sagre-Barboza, A.; Anaya, C., \& Pastrana, J. (2021). Reading to Learn and EFL students' construction of spoken biographical recounts. Íkala, Revista de Lenguaje y Cultura, 26(1), 41-60. https://doi.org/10.17533/udea.ikala.v26n01a06 